\title{
TEKANAN POLITIK PEMERINTAH DAERAH \\ DALAM ALOKASI DAU
}

\author{
Syarif Syahrial ${ }^{1)}$
}

\begin{abstract}
A bstract
The paper analyzes the current progress of the fiscal decentralization in Indonesia, characterized by the pressure to improve the law, UU No. 22 and 25199. We apply the probit model on the municipality data in 2002, and estimate the block grant size (DAU) as a function of fiscal needs, the size of region and collusion between central and local government.

The result conform the significance of political pressure from rich region to central government, but fail to prove the positive hypothetical relationship between the block grant size and the collusion. The implication is straight forward, that the implementation of the fiscal decentralization must be strengthen to avoid miss allocation of the fund.
\end{abstract}

Keywords: Fiscal policy, decentralization, collussion, probit model

JEL Classification: C35, E62

1 Penulis adalah peneliti dan staff pengajar di Fakultas Ekonomi, Universitas Indonesia. andi_syarif97@yahoo.com 


\section{PENDAHULUAN}

Tak dapat dipungkiri bahwa desentralisasi fiskal di Indonesia merupakan suatu revolusi yang sangat besar dalam kehidupan manajemen keuangan publik di Indonesia. Perubahan yang sangat mendasar dari sistem yang tersentralisasi secara penuh pada Era Orde Baru menjadi sistem yang terdesentralisir. Desentralisasi Fiskal dan Otonomi Daerah yang ditandai dengan berlakunya UU No. 22 dan 25 Tahun 1999 layaknya sebuah "big bang" dalam penciptaan bumi. Layaknya suatu revolusi besar, maka masih dirasakan banyak kekurangan dalam implementasi desentralisasi fiskal tersebut. Hal ini ditandai dengan mencuatnya isu untuk menyempurnakan perundang-undangan yang mengatur tentang Otonomi Daerah tersebut. ${ }^{2}$

Periode awal implementasi desentralisasi fiskal ditandai dengan masih tingginya ketergantungan pemerintah daerah terhadap dana transfer dari pemerintah pusat khususnya Pemerintah Kabupaten/Kota. ${ }^{3}$ Dana transfer dari pemerintah pusat kepada pemerintah daerah tersebut dalam bentuk Dana Alokasi Umum, Dana Alokasi Khusus serta Dana Bagi Hasil baik yang menyangkut Bagi Hasil Pajak dan Bukan Pajak (Sumber Daya Alam). Studi yang dilakukan Syahrial (2004) terhadap Data Konsolidasi APBD Provinsi dan Kabupaten/Kota pada tahun 2001 menunjukkan bahwa secara rata-rata 76,5\% keseluruhan APBD berasal dari dana perimbangan tersebut. ${ }^{4}$

Dari sisi keuangan pemerintah pusat dalam APBN, pelaksanaan otonomi daerah dan desentralisasi fiskal telah memberikan pengaruh yang sangat besar terhadap pengeluaran pemerintah pusat yang harus di daerahkan dalam bentuk dana perimbangan. Sejak 1994/ 1995 - 2000, Dana perimbangan ini berkisar dari Rp 14,6 trilyun hingga Rp 33 trilyun pada tahun 2000. Setelah adanya otonomi daerah, pada tahun 2001 jumlah ini meningkat sebesar $145 \%$ menjadi Rp 81 trilyun. Peningkatan yang sangat fantastis ini tidak terlepas dari pendelegasian wewenang yang lebih besar kepada daerah dalam proses pembangunan di daerahnya masing-masing. Jumlah ini terus meningkat menjadi Rp 107,5 trilyun ditambah dengan dana otonomi khusus dan dana penyeimbang sebesar Rp 9,4 trilyun. Dari keseluruhan dana yang disalurkan oleh pemerintah pusat kepada pemerintah daerah tersebut, Dana Alokasi Umum (DAU) merupakan komponen terbesar yang disalurkan oleh pemerintah pusat kepada pemerintah daerah yaitu sebesar $66 \%$ dari total dana APBN yang didaerahkan disusul dengan Dana Bagi Hasil sebesar 24\%. ${ }^{5}$

2 UU No. 22 Tahun 1999 tentang Pemerintahan Daerah dan UU No. 25 Tahun 1999 tentang Perimbangan Keuangan antara Pemerintah Pusat dan Daerah

3 Usui, Nario and Armida Alisjahbana. Local Development Planning and Budgeting in Decentralized Indonesia: Key Issues. A Paper Presented in Indonesian-Japanese on Indonesia's Decentralization, 2003

4 Syahrial, Syarif. Fiscal Decentralization and Government Size: The Case Study of Indonesia (forthcoming)

5 Diolah dari Nota Keuangan Republik Indonesia, Departemen Keuangan RI, berbagai tahun penerbitan. 
Besarnya jumlah dana perimbangan khususnya DAU serta tingginya ketergantungan daerah terhadap DAU tersebut telah berimplikasi terhadap tingginya tekanan politis dalam alokasi DAU kepada masing-masing daerah. Tekanan politis itu disinyalir dengan masih kentalnya pengaruh daerah kaya serta daerah yang tinggi sumber daya alamnya terhadap formulasi pembagian DAU kepada masing-masing daerah. Di sisi yang lain, DAU bertujuan untuk melakukan pemerataan pembangunan antar daerah dan telah dibagi dengan menggunakan bobot yang berasal dari formulasi tertentu.

Tingginya tekanan politis daerah terhadap pemerintah pusat ini, membawa penulis untuk mengungkapkan lebih jauh tentang probabilitas daerah untuk menerima DAU di atas ratarata. Apakah didasari pada faktor kebutuhan fiskal daerah, atau apakah dikarenakan tekanan politik daerah kaya khususnya daerah penghasil SDA, atau dikarenakan besarnya faktor lobi dari pemerintah daerah kepada pemerintah pusat.

\section{TINJAUAN LITERATUR}

Proses desentralisasi di negara manapun tidak terlepas dari dana transfer pemerintah pusat kepada pemerintah daerah agar daerah mampu menjalankan kewenangan yang diberikan oleh pemerintah pusat kepada pemerintah daerah. Begitu pula dengan Indonesia, yang berdasarkan UU No. 22/1999 telah dengan jelas memberikan kewenangan wajib bagi pemerintah daerah. Untuk melakukan kewenangan tersebut, berdasarkan UU No. 25/1999 pasal 6, telah mencantumkan bahwa dana perimbangan dari pemerintah pusat kepada pemerintah daerah tersebut berupa Dana Alokasi Umum, Dana Alokasi Khusus, serta Dana Bagi Hasil baik yang berupa Bagi Hasil Pajak dan Bukan Pajak (Sumber Daya Alam). ${ }^{6}$

Dalam perkembangannya, DAU merupakan komponen utama dan memiliki jumlah anggaran terbesar dalam Dana Perimbangan sehingga signifikansi dari aliran DAU bagi daerah sangatlah berarti dan bahkan cenderung menentukan besarnya alokasi pengeluaran pemerintah daerah yang pada akhirnya akan berimplikasi terhadap proses pembangunan di daerah. Selain Dana Perimbangan yang ada, pada tahun 2002, muncul tuntutan dari berbagai daerah yang tidak mau menerima alokasi DAU yang lebih rendah dari tahun sebelumnya yang dikenal sebagai hold harmless. Adanya hold harmless inilah yang mengakibatkan DAU tidak dapat menerapkan formula secara penuh yang mempengaruhi kinerja DAU sebagai alat pemerataan.

Karena adanya hold harmless ini lah, muncul unsur dana perimbangan dari pemerintah pusat kepada pemerintah daerah yang berupa Dana Penyeimbang (DP). Dana Penyeimbang ini

6 Pasal 6 UU No.25 Tahun 1999 tentang Perimbangan Keuangan antara Pemerintah Pusat dan Daerah 
berkembang lagi menjadi DP Murni dan DP Adhoc. DP murni ini lah yang merupakan komponen hold harmless yang dikeluarkan untuk menutupi daerah yang mendapatkan DAU yang lebih rendah dari tahun sebelumnya. DP Adhoc merupakan DP yang dikeluarkan berkaitan dengan kebijakan pemerintah pusat untuk memberikan gaji ke-13 kepada seluruh Pegawai Negeri Sipil. Selain DP, pada tahun 2001 juga, pemerintah pusat mengambil kebijakan yang bersifat khusus, yaitu memberlakukan otonomi khusus di Papua dan Nanggroe Aceh Darussalam yang ditandai dengan berlakunya UU No. 18 dan 21 Tahun 2001. Adanya otonomi khusus ini memberikan implikasi bagi APBN dengan munculnya item pengeluaran APBN yang didaerahkan yaitu Dana Otonomi Khusus. ${ }^{7}$

Perkembangan DAU akhirnya tidak terlepaskan juga dari perkembangan DP Murni karena DP Murni ini pun dimasukkan dalam formula terutama dikaitkan dengan keinginan agar hold harmless tetap terjaga. DAU sendiri diformulasikan dengan pertimbangan kesenjangan fiskal. Formulasi kesenjangan fiskal mempertimbangkan kebutuhan dan kapasitas fiskal sesuai dengan amanat UU No 25/1999.

Brodjonegoro dan Mahi (2003) mengindikasikan bahwa setelah 2 tahun implementasi desentralisasi fiskal di Indonesia, prinsip kemerataan dalam alokasi DAU masih jauh dari optimal yang diindikasikan oleh formula DAU saat ini. Formula DAU masih memiliki unsur lumpsum serta adanya akomodasi terhadap hold harmless terutama dari tekanan politik dari daerah kaya sumber daya alam dan DKI Jakarta. Semakin besar komponen lumpsum, semakin kurang pemerataan dalam alokasi DAU. Adanya komponen hold harmless ini menunjukkan adanya tekanan politik dalam kebijakan fiskal nasional terutama dikarenakan adanya kurang kepercayaan antara pemerintah pusat dan daerah. ${ }^{8}$

Selain tekanan politik dari daerah kaya, desentralisasi fiskal juga memunculkan potensi adanya kolusi antar level pemerintahan, seperti yang dihipotesiskan oleh Brennan dan Buchanan. Hipotesis kolusi yang dikembangkan oleh Brennan/Buchanan (Brennan/Buchanan Collusion Hypothesis) menyatakan bahwa ketika desentralisasi tidak memperkuat kompetisi antar pemerintah daerah, pengeluaran daerah menjadi meningkat. Terkadang untuk membiayai pengeluaran tersebut telah terjadi kolusi antar pemerintah daerah termasuk dengan pemerintah pusat serta membiayai pengeluaran daerah melalui dana bagi hasil (dana perimbangan). ${ }^{9}$

Penulis sendiri pernah melakukan studi antara hubungan desentralisasi fiskal dan ukuran pemerintah. Dari studi tersebut dapat disimpulkan bahwa ketergantungan yang tinggi dari

7 Syahrial, Syarif. Otonomi Khusus: Tinjauan Singkat dari Sisi Perekonomian dan Keuangan Daerah. Wacana Alumni Diklat LPEM FEUI.

8 Brodjonegoro and Mahi. The Indonesian Political Economy of Decentralization. A Paper Presented in Indonesian-Japanese on Indonesia's Decentralization, 2003

9 Brennan, G and JM Buchanan. The Power to Tax: Analytical Foundations of a Fiscal Constitution (Cambridge: Cambridge University Press) 
pemerintah daerah terhadap dana perimbangan yang disalurkan oleh pemerintah pusat mengindikasikan adanya kandungan politik yang tinggi dalam penyaluran dana alokasi yang bermuara adanya kolusi antar level pemerintahan. Pemerintahan daerah terbukti tidak melakukan kompetisi antar pemerintahan daerah, dan sangat bergantung pada pengeluaran yang dibiayai melalui dana alokasi dari pemerintah pusat (Syahrial, 2004). ${ }^{10}$

Adanya indikasi awal munculnya kolusi antar level pemerintah ini memberikan konsekuensi adanya kemungkinan munculnya dorongan dari pemerintah daerah untuk melakukan usaha kollutif dengan aparat pemerintah pusat. Usaha ini dilakukan agar dapat memperoleh tambahan DAU bagi proses pembangunan di daerahnya. Tidak dapat dipungkiri usaha ini tidak terlepas dari kondisi pemerintahan yang buruk di Indonesia seperti yang terlihat pada sejumlah studi yang dilakukan. Sehingga diharapkan setelah mendapat tambahan DAU maka semakin besar pula kesempatan untuk memperkaya diri sendiri. Sikap pesimistis ini memang perlu dibuktikan secara ilmiah dan bukan hanya bersifat dugaan tanpa dasar belaka. Pada bab berikut ini, penulis akan menggambarkan kerangkapikir konseptual dalam usaha penulis membuktikan ada atau tidaknya dugaan tersebut dalam alokasi DAU di Indonesia.

\section{KERANGKAPIKIR KONSEPTUAL}

Untuk mengetahui probabilitas daerah menerima DAU di atas rata-rata, sangat dipengaruhi oleh berbagai macam faktor. Dari tujuan literatur pada bab sebelumnya, secara garis besar dapat kita kelompokkan pada 3 kelompok besar variabel penjelas yaitu variabel yang mencerminkan faktor kebutuhan fiskal, variabel yang mencerminkan kondisi daerah baik dari sisi fiskal daerah dan ukuran perekonomian daerah, serta variabel yang mencerminkan kolusi antar level pemerintahan.

Dari sisi kebutuhan fiskal, secara teoritis dari penyaluran DAU berdasarkan formula, variabel kebutuhan fiskal seharusnya memiliki hubungan yang positif dengan besarnya DAU yang diterima untuk masing-masing daerah. Dengan kata lain, daerah yang memiliki kebutuhan fiskal yang besar akan memiliki probabilitas yang besar pula untuk menerima DAU di atas ratarata. Dalam formula perhitungan DAU yang dilakukan oleh Direktorat Jenderal Perimbangan Keuangan Pusat dan Daerah (Dirjen PKPD), variabel kebutuhan fiskal tersebut dicerminkan melalui variabel kependudukan dan kewilayahan. ${ }^{11}$

Dari sisi kependudukan, digunakan variabel Jumlah Penduduk serta Indeks Kemiskinan Relatif. Dari sisi kewilayahan, digunakan variabel luas wilayah dan indeks kemahalan konstruksi.

10 Syahrial, Syarif. Fiscal Decentralization and Government Size: The Case Study of Indonesia (forthcoming, 2004) 11 Sidik, Machfud et.all. Dana Alokasi Umum. Dirjen PKPD, MPKP FEUI dan LPEM FEUI (Jakarta: 2002) 
Dalam penelitian ini, penulis akan mengambil satu variabel kependudukan dan kewilayahan. Dari sisi kependudukan, penulis akan menggunakan proporsi penduduk miskin terhadap total penduduk. Dari variabel ini, dihipotesiskan bahwa proporsi penduduk miskin terhadap total penduduk memiliki hubungan yang positif dan signifikan terhadap probabilitas daerah menerima DAU di atas rata-rata. Dari sisi kewilayahan, penulis akan berusaha menggunakan variabel luas wilayah. Pemilihan variabel ini tidak terlepas dari asumsi dasar bahwa daerah yang memiliki wilayah yang lebih luas akan memiliki probabilitas yang lebih besar pula untuk menerima DAU di atas rata-rata. Dengan kata lain, luas wilayah memiliki hubungan yang positif dan signifikan dalam mempengaruhi probabilitas daerah menerima DAU di atas rata-rata.

Kelompok variabel kedua dalam mempengaruhi probabilitas daerah menerima DAU di atas rata-rata adalah variabel yang mencerminkan kondisi daerah. Seperti yang diungkapkan dalam bagian tinjauan literatur, terlihat bahwa terdapat tekanan politik dari daerah kaya yang mempengaruhi alokasi DAU. Untuk kepentingan mengetahui hal ini, penulis berusaha menangkap apakah terdapat hubungan antara kondisi daerah dalam mempengaruhi probabilitas daerah menerima DAU di atas rata-rata. Variabel yang menggambarkan kondisi daerah ini meliputi dua aspek yaitu dari sisi fiskal daerah dan ukuran perekonomian daerah.

Dari sisi fiskal daerah, penulis akan menggunakan dua variabel yaitu besarnya Pendapatan Asli Daerah dan Bagi Hasil Sumber Daya Alam (BHSDA). Kedua variabel ini dalam formula DAU merupakan variabel kapasitas fiskal serta faktor negatif dalam perhitungan DAU yang menggunakan konsep kesenjangan fiskal. Dengan kata lain, daerah yang memiliki diestimasikan memiliki PAD yang besar dan jumlah BHSDA yang besar akan secara teoritis akan mendapatkan DAU yang lebih kecil. Dengan kata lain, besarnya estimasi PAD dan BHSDA akan berhubungan negatif terhadap probabilitas daerah menerima DAU yang lebih besar daripada rata-rata. Penulis berusaha membuktikan hal ini tidak terlepas dari adanya dugaan tentang tekanan politik daerah terhadap alokasi DAU. Selain itu, estimasi PAD terkadang tidak mencerminkan kondisi sesungguhnya dan cenderung underestimate sehingga memberikan faktor pengurang yang relatif sedikit. Faktor lain adalah masih besarnya komponen lumpsum yang termasuk dalam alokasi minimum dalam penyaluran DAU.

Berdasarkan hal ini, jika didominasi oleh tekanan politik, maka daerah yang memiliki PAD dan BHSDA yang besar, dimungkinkan akan menerima DAU yang besar pula. Dengan kata lain, PAD dan BHSDA memiliki hubungan yang positif dan signifikan terhadap probabilitas daerah menerima DAU di atas rata-rata. Hipotesis yang berlawanan dengan hipotesis pada kapasitas fiskal tidak terlepas dari dugaan bahwa daerah yang memiliki PAD dan BHSDA yang besar memiliki cukup dana untuk mendesak pemerintah pusat untuk mengalokasikan 
DAU yang lebih besar kepada daerah tersebut. Dengan kata lain, fenomena kolusi antar level pemerintah pun dimungkinkan terjadi bila hubungan yang positif ini terbukti.

Hubungan antara variabel kolusi dan probabilitas menerima DAU ini juga tidak terlepas dari literatur pada bab sebelumnya. Dalam hipotesis kolusi Brennan dan Buchanan terlihat bahwa dimungkinkan terjadi kolusi antar level pemerintahan. Selain itu, penelitian yang dilakukan oleh de Mello ${ }^{12}$ untuk kasus Moldova serta yang dilakukan oleh Syahrial (2004) untuk kasus Indonesia juga mengintrodusir unsur ini dalam usahanya memperlihatkan hubungan antara desentralisasi fiskal dan ukuran pemerintahan. Dalam kerangka praktek untuk memperlihatkan kolusi antar level pemerintahan ini, sulit ditemukan literatur yang mengintrodusir hal ini.

Kesulitan yang sama untuk mewakili variabel kolusi antara aparat pemerintahan yaitu antara aparat pemerintah daerah dan pemerintah pusat juga ditemukan oleh penulis. Oleh karena itu, penulis berusaha mendekatkan usaha kolusi antar level pemerintahan tersebut dalam bentuk mata anggaran Biaya Perjalanan Dinas. Proksi ini dilakukan tidak terlepas dari isu yang berkembang yang dikenal sebagai KISS (ke ibukota sendiri-sendiri). Isu ini berkaitan dengan sejumlah usaha lobi aparat pemerintah daerah yang datang ibukota Jakarta untuk menemui aparat pemerintah pusat dalam upaya mendapatkan alokasi DAU yang lebih besar lagi.

Pendekatan proksi ini tidak terlepas dari asumsi bahwa Biaya Perjalanan Dinas tersebut mencerminkan usaha aparat pemerintah daerah ke Jakarta untuk mendekati dalam usaha kolusi dengan aparat pemerintah pusat. Asumsi ini memang cenderung lemah dikarenakan dalam mata anggaran tersebut tidak rinci bahwa seluruh Biaya Perjalanan Dinas digunakan untuk ke Jakarta apalagi digunakan untuk usaha melobi. Namun, dikarenakan keterbatasan data, maka penulis berusaha mendapatkan sedikit clue dari penggunaan variabel ini. Biaya perjalanan dinas dihipotesiskan memiliki pengaruh yang positif dan signifikan dalam mempengaruhi besarnya probabilitas daerah menerima DAU di atas rata-rata.

\section{MODEL DAN PROSEDUR ESTIMASI}

Berdasarkan pada bagian sebelumnya, terlihat bahwa model yang akan kita bangun berusaha menghubungkan probabilitas daerah menerima DAU di atas rata sebagai fungsi dari proporsi penduduk miskin terhadap total penduduk, luas wilayah, besarnya PAD, besarnya BHSDA serta besarnya Biaya Perjalanan Dinas untuk masing-masing daerah. Karena bentuk variabel terikat yang kita gunakan berbentuk diskrit, dimana variabel tersebut memiliki dua nilai yaitu 1 untuk daerah yang memiliki DAU di atas rata-rata dan 0 untuk daerah yang memiliki

12 Mello de, Luiz. Fiscal Decentralization and Government Size: Case of Moldova (IMF Working Paper: 2003) 
DAU di bawah rata-rata, maka bentuk model yang kita gunakan, secara teknik ekonometrika, termasuk dalam model dengan variabel terikat diskrit (Discrete Dependent Variabel Model).

Sesuai teori, setidak-tidaknya terdapat tiga model dalam teknik estimasi model variabel terikat diskrit yaitu Model Probabilitas Linier, Model Probit serta Model Logit. ${ }^{13}$ Dalam penelitian ini, penulis akan menggunakan model probit dalam proses estimasi. Pemilihan model ini tidak terlepas dari bentuk distribusi probabilitas yang mengikuti distribusi normal. Secara matematis, model probit untuk tujuan estimasi yang kita buat dapat ditunjukkan sebagai berikut:

$$
D A U_{i}=\beta_{0}+\beta_{1}{ }^{*} P O O R_{i}+\beta_{2}{ }^{*} W I L_{i}+\beta_{3}{ }^{*} B H S D A_{i}+\beta_{4}{ }^{*} B E L D I N_{i}+\beta_{5}{ }^{*} P A D_{i}+\varepsilon_{\mathrm{i}}
$$

Dimana: $\mathrm{DAU}_{\mathrm{i}}=$ jumlah DAU ditambah dengan DP Murni setiap kabupaten/kota, jika di atas rata-rata (1) dan di bawah rata-rata $(0), \mathrm{POOR}_{\mathrm{i}}=$ rasio penduduk miskin terhadap total penduduk untuk setiap kabupaten/kota, $\mathrm{WIL}_{\mathrm{i}}=$ luas wilayah untuk setiap kabupaten/kota, BHSDA $_{\mathrm{i}}=$ Jumlah Bagi Hasil Sumber Daya Alam untuk setiap kabupaten/kota, serta BELDIN ${ }_{\mathrm{i}}=$ Biaya Perjalanan Dinas untuk setiap kabupaten/kota, $P A D_{i}=$ Jumlah Pendapatan Asli Daerah untuk setiap kabupaten/kota serta $\mathrm{e}_{\mathrm{i}}$ sebagai komponen galat (error terms).

Dalam teori ekonometrika yang berkaitan dengan model variabel terikat terbatas (limited dependent variable), model 1 di atas dapat diestimasi dengan menggunakan model probabilitas linier dengan menggunakan teknik kudrat terkecil sederhana. Namun, model probabilitas linier ini memiliki kelemahan yang berkaitan nilai probabilitas yang dimungkinkan lebih kecil dari 0 atau lebih besar daripada 1 selain adanya masalah heteroskedastisitas yang mengakibatkan koefisien estimasi menjadi tidak terbaik dalam kriteria BLUE (Best Liniear Unbiased Estimator). ${ }^{14}$ Karena itu lah, penulis menggunakan model Probit yang memiliki sedikit perbedaan dengan model probabilitas linier yaitu dengan menggunakan fungsi distribusi probabilitas normal. Persamaan 1 di atas dapat diubah menjadi bentuk model probit seperti terlihat berikut ini:

$$
\operatorname{Pr}(\mathrm{DAU}=1 / \mathrm{X})=\Phi\left(\beta_{0}+\beta_{1}{ }^{*} P O O R_{i}+\beta_{2}{ }^{*} W L_{i}+\beta_{3}{ }^{*} B H S D A_{i}+\beta_{4}{ }^{*} B E L D I N_{i}+\beta_{5}{ }^{*} P A D_{i}\right)
$$

dimana $\Phi$ merupakan distribusi probabilitas normal kumulatif serta DAU diobservasi pada nilai 0 dan 1 saja serta $X$ merupakan satu kondisional dari variabel penjelas.

Munculnya unsur $\Phi$ menunjukkan dengan jelas bahwa bentuk persamaan kita menjadi non linier. Hal ini membuat interpretasi dari koefisien hasil estimasi menjadi sedikit lebih sulit dari koefisien estimasi persamaan regresi biasa. Koefisien hasil estimasi dengan menggunakan model Probit ini diperoleh dengan menggunakan metode estimasi Maximum Likelihood. Meskipun demikian, kita masih bisa melakukan interpretasi seperti biasa untuk arah

13 Ghozali, Abbas. Modul Ekonometrika II Pascasarjana Ilmu Ekonomi FEUI. Catatan Kuliah (Jakarta:2004)

14 Verbeek, Marno. A Guide to Modern Econometrics. (Chichester: John Wiley \& Sons, 2000) hal. 178 
(magnitute) dari koefisien estimasi serta signifikansi dari koefisien estimasi (yang ditunjukkan dengan nilai z statistik).

\section{SAMPEL DAN SUMBER DATA}

Berdasarkan model dan metode estimasi yang telah dijabarkan sebelumnya, maka diperlukan data untuk mewakili variabel yang telah digunakan dalam model. Data dalam penggunaan model probit ini bersifat data kerat lintang (cross section data). Untuk melihat kemungkinan daerah menerima DAU di atas rata-rata maka penulis menggunakan sampel daerah Kabupaten/Kota seluruh Indonesia untuk alokasi DAU pada tahun 2002. Kebutuhan data serta sumber data untuk mewakili variabel tersebut secara sistematis dapat dijelaskan berikut ini.

\section{V.1 Besar Alokasi DAU}

Sebagai variabel terikat dalam model kita ini adalah besarnya DAU. Namun, seperti yang telah terlihat dalam tinjauan literatur bahwa terdapat sejumlah kerentanan dari daerah untuk tidak mau DAU nya turun dibandingkan dengan tahun sebelumnya (hold harmless). Untuk menjaga hold harmless ini lah, maka pemerintah pusat menjamin agar DAU tahun 2002 tidak lebih kecil dibandingkan dengan DAU 2001 dengan menambah Dana Penyeimbang (DP) Murni. Oleh karena itu, dalam studi ini, penulis menggunakan besarnya DAU ditambah dengan DP Murni untuk setiap kabupaten/kota. Formulasi untuk menentukan besarnya DP Murni ini tidak terlepas dari formulasi besarnya DAU yang diterima untuk masing-masing daerah.

Untuk membuat variabel terikat ini menjadi diskrit, maka kita bagi nilai DAU untuk masingmasing kabupaten/kota yang di atas rata-rata atau dibawah rata-rata. Daerah yang memiliki nilai DAU di atas rata-rata kita berikan nilai 1 sedangkan daerah yang memiliki nilai DAU dibawah rata-rata dengan nilai 0 . Dalam sampel kabupaten/kota yang kita gunakan dalam penelitian ini, nilai DAU rata-rata untuk keseluruhan kabupaten/kota daerah sampel memiliki nilai sebesar Rp 186 Milyar.

\section{V.2 Proporsi Penduduk Miskin terhadap Total Penduduk}

Variabel penjelas yang pertama kita gunakan dalam model estimasi ini adalah proporsi penduduk miskin terhadap total jumlah penduduk (nama variabel ini adalah poor). Variabel poor ini diperoleh dengan membagi jumlah penduduk miskin dengan total jumlah penduduk. Data ini bersumber dari Badan Pusat Statistik yang memberikan data kepada Direktorat Jenderal 
Perimbangan Keuangan Pusat dan Daerah dalam kerangka data dasar penyusunan DAU tahun 2002. Untuk kerangka penyusunan DAU 2002, maka digunakan porsi penduduk miskin terhadap total penduduk tahun 2001.

\section{V.3 Luas Wilayah}

Variabel penjelas berikutnya adalah luas wilayah. Untuk penyusunan DAU 2002, maka digunakan data luas wilayah yang berasal dari Keputusan Menteri Dalam Negeri tahun 2001 tentang Luas Wilayah. Agar diperoleh bentuk data yang kategorikal, maka penulis membagi data ini menjadi empat berdasarkan nilai kuartilnya. Dari hasil perhitungan, terlihat bahwa nilai kuartil pertama dari luas wilayah adalah 788,64 km2, kuartil kedua sama dengan 1.883,32 km2 serta kuartil ketiga bernilai $5.901,3 \mathrm{~km} 2$. Daerah yang memiliki luas wilayah dibawah $788,64 \mathrm{~km} 2$ diberikan nilai 1, daerah dengan luas wilayah antara 788,64 - 1.883,32 km2 diberi nilai 2, daerah dengan luas wilayah antara 1.883,32 - 5.901,3 km2 diberi nilai 3 serta daerah dengan luas wilayah di atas $5.901,3 \mathrm{~km} 2$ diberi nilai 4 .

\section{V.4 Besarnya PAD}

Pendapatan Asli Daerah (PAD) merupakan variabel penjelas berikutnya yang kita gunakan dalam penelitian ini. Untuk melihat pengaruhnya terhadap penentuan DAU 2002, maka kita gunakan PAD tahun 2001. Berbeda dengan formulasi yang ada dalam DAU 2002, pemerintah menggunakan data PAD tahun 2000. Penggunaan PAD tahun 2001 ini tidak terlepas dari keinginan penulis untuk memperlihatkan pengaruh daerah kaya dalam memperoleh DAU yang besar. Secara teoritis, PAD ini harusnya berhubungan negatif terhadap penerimaan DAU. Namun dengan PAD yang tinggi, daerah kaya mampu untuk mempengaruhi pemerintah pusat untuk memperoleh DAU di atas rata-rata.

Data PAD tahun 2001 ini diperoleh penulis dari Data Konsolidasi Anggaran Pendapatan dan Belanja Daerah (APBD) tahun 2001 yang dipublikasikan di Dirjen PKPD Departemen Keuangan RI. Seperti halnya dengan luas wilayah, maka data PAD ini pun penulis kategorikan berdasarkan nilai kuartilnya. Dari hasil perhitungan penulis, nilai kuartil pertama dari PAD itu adalah Rp 4.476,39 juta, kuartil kedua sama dengan Rp 8.376,28 juta, serta kuartil ketiga adalah Rp 17.669, 89 juta. Data PAD tersebut dikategorikan dengan aturan sebagai berikut: nilai PAD yang lebih kecil dari Rp 4.476,39 juta diberikan angka 1, nilai PAD antara Rp 4.476,39 juta - Rp 8.376,28 juta diberikan angka 2, nilai PAD antara Rp 8.376,28 juta Rp 17.669, 89 juta diberikan angka 3 serta nilai PAD yang di atas Rp 17.669, 89 juta diberikan angka 4. 


\section{V.5 Besarnya BHSDA}

Variabel bebas yang lain adalah Bagi Hasil Sumber Daya Alam (BHSDA). Data BHSDA yang digunakan dalam penelitian ini adalah BHSDA 2001. Data tentang BHSDA 2001 ini diperoleh dari publikasi Dirjen PKPD atas Keputusan Menteri Keuangan tentang Pagu Bagi Hasil Sumber Daya Alam. Seperti pada variabel PAD dan Luas Wilayah, penulis juga melakukan kategori terhadap data BHSDA dengan menggunakan nilai kuartil dari data tersebut. Dari hasil perhitungan, kuartil pertama dari nilai BHSDA adalah Rp 1.549,43 Juta, kuartil kedua Rp 2.721,68 juta, serta kuartil ketiga adalah Rp 10.008,59 juta. Kategori nilai BHSDA ini adalah sebagai berikut: nilai BHSDA lebih kecil dari Rp 1.549,43 juta diberi nilai 1, nilai BHSDA antara Rp 1.549,43 Juta - Rp 2.721,68 juta diberi nilai 2, nilai BHSDA antara Rp 2.721,68 juta - Rp 10.008,59 juta diberi nilai 3, serta nilai BHSDA di atas Rp 10.008,59 juta diberi nilai 4.

\section{V.6 Biaya Perjalanan Dinas}

Variabel penjelas terakhir adalah Biaya Perjalanan Dinas. Variabel biaya perjalanan dinas ini dapat diperoleh datanya dari Data Konsolidasi Anggaran Pendapatan dan Belanja Daerah (APBD) tahun 2001 yang dipublikasikan di Dirjen PKPD Departemen Keuangan RI. Biaya perjalanan dinas ini merupakan salah satu komponen dalam pengeluaran rutin dalam APBD.

Seperti halnya dengan PAD, Luas Wilayah dan BHSDA, variabel Biaya Perjalanan Dinas ini juga kita kategorikan berdasarkan nilai kuartilnya. Hasil perhitungan menunjukkan nilai kuartil pertama dari Biaya Perjalanan Dinas adalah Rp 613,91 juta, kuartil kedua adalah Rp 1.053,55 juta, serta kuartil ketiga adalah Rp 1.868,56 juta. Aturan pengkategorisasian variabel Biaya Perjalanan Dinas ini adalah sebagai berikut: Biaya Perjalanan Dinas yang lebih kecil dari Rp 613,91 juta diberi angka 1, Biaya Perjalanan Dinas antara Rp 613,91 juta - Rp 1.053,55 juta diberi angka 2, Biaya Perjalanan Dinas antara Rp 1.053,55 juta - 1.868,56 juta diberi angka 3, serta Biaya Perjalanan Dinas di atas 1.868,56 juta diberi angka 4.

Pada bagian selanjutnya, kita akan melihat hasil estimasi model yang kita gunakan dengan menggunakan data yang ada.

\section{HASIL DAN PEMBAHASAN}

\section{VI.1 Hasil}

Dari model ekonometrika yang dibangun serta didukung dengan data-data yang digunakan sebagai proksi terhadap variabel yang kita gunakan, maka dilakukan proses estimasi dengan menggunakan teknik estimasi model probit. Seperti yang telah dinyatakan dalam 
andasan teori yang dinyatakan sebelumnya, bahwa terdapat permasalahan heteroskedastisitas dalam estimasi model probit dan karenanya kita harus melakukan proses estimasi dengan menggunakan pilihan generalized linear model (GLM). Hasil estimasi dengan menggunakan pilihan GLM ini dapat ditunjukkan berikut ini:

$\operatorname{Prob}(D A U=1)=\Phi(-2.78+3.12 * P O O R+0.77 * P A D-0.11 * B H S D A-0.17 * B E L D I N+0.21 * W I L)$

$\begin{array}{lllll}(-6,93) & (5,38) \quad(8,56) \quad(-1,37) \quad(-2,01) \quad(2,18)\end{array}$

Nilai didalam kurung menunjukkan z statistics.

Bagian pertama dari hasil ini yang perlu dilihat adalah signifikansi variabel penjelas dalam menjelaskan variabel terikat. Untuk mengetahui signifikansi ini kita gunakan nilai statistik z yang dihitung dengan menggunakan rasio antara koefisien hasil estimasi dengan galat baku. Dengan menggunakan hipotesis nol bahwa koefisien sama dengan nol (tidak mempengaruhi variabel penjelas) kita dapat mempergunakan nilai statistik z yang diperbandingkan dengan nilai z tabel. Dasar penerimaan atau penolakan terhadap hipotesis nol ini mirip dengan penggunaan statistik $t$ dalam estimasi model kuadrat terkecil sederhana (OLS). Selain itu, kita juga menggunakan nilai probabilitas dari statistik z tersebut sebagai dasar penolakan atau penerimaan hipotesis nol. Jika nilai probabilitas tersebut lebih kecil dari level signifikansi (misalnya $5 \%)$, maka cukup bukti untuk kita untuk menolak hipotesis nol, atau dengan kata lain, variabel penjelas tersebut signifikan dalam mempengaruhi variabel terikat.

Hasil estimasi yang kita lakukan menunjukkan bahwa hampir keseluruhan variabel penjelas dalam model memiliki pengaruh yang signifikan dengan menggunakan level signifikansi 5\% kecuali variabel bagi hasil sumber daya alam (BHSDA). Variabel BHSDA tersebut secara statistik tidak signifikan dalam menjelaskan variabel terikat atau dengan kata lain koefisien variabel BHSDA dalam menjelaskan DAU secara statistik tidak ada bedanya dengan nol.

Selain signifikansi, arah pengaruh variabel penjelas dapat langsung kita interpretasikan secara langsung (tidak berbeda dengan estimasi metode kuadrat terkecil sederhana). Hasil pengujian menunjukkan bahwa nilai PAD berpengaruh positif dan signifikan dalam mempengaruhi probabilitas daerah memperoleh DAU di atas rata-rata. Setiap peningkatan nilai PAD akan dapat meningkatkan probabilitas daerah menerima DAU di atas rata-rata dan begitu juga sebaliknya. Proporsi penduduk miskin terhadap total penduduk (POOR) juga memiliki pengaruh yang positif dan signifikan dalam mempengaruhi probabilitas daerah menerima DAU di atas rata-rata begitu pula dengan luas wilayah yang juga berhubungan positif dengan variabel penjelas. BHSDA memiliki pengaruh negatif dan tidak signifikan dalam mempengaruhi variabel penjelas, namun Belanja Perjalanan Dinas (BELDIN) memiliki pengaruh negatif dan signifikan 
dalam menjelaskan variabel terikat. Kondisi ini menunjukkan setiap peningkatan belanja perjalanan dinas akan dapat menurutkan probabilitas daerah menerima DAU di atas rata-rata.

Ukuran ketiga yang penting dari suatu model estimasi adalah kinerja dari model estimasi. Dalam model probit, hal ini dapat ditunjukkan nilai statistik LR (Likelihood Ratio) yang dalam metode kuadrat terkecil sederhana (OLS) ditunjukkan oleh nilai statistik F. Karenanya, pengujian tentang kinerja dari model tersebut merupakan pengujian signifikansi secara bersama (joint significant test). Dalam model probit, hipotesis bersama yang diujikan adalah nilai seluruh koefisien variabel penjelas (slope) kecuali konstanta bernilai nol. Dasar penolakan/penerimaan terhadap hipotesis nol tersebut adalah nilai statistik LR yang dihitung dengan formula -2 (restricted log likelihood - average log likelihood). Nilai statistik LR ini mengikuti distribusi dari statistik Kai Kuadrat $\left(\chi^{2}\right)$ dengan derajat kebebasan sebanyak variabel penjelasnya (dalam model kita sama dengan 5). Jika nilai statistik LR lebih besar dibandingkan dengan nilai $\chi^{2}$ tabel. Dengan kata lain, variabel penjelas secara bersama-sama signifikan dalam menjelaskan variabel terikat. Dalam software yang digunakan oleh penulis, juga dicantumkan nilai Probabilitas dari LR Statistik tersebut. Jika nilai probabilitas tersebut lebih besar dari 5\% (level signifikansi) maka cukup bukti untuk tidak menolak hipotesis nol, atau dengan kata lain, variabel penjelas secara bersamasama tidak signifikan dalam menjelaskan variabel terikat.

Hasil estimasi yang kita lakukan menunjukkan bahwa nilai LR statistik sebesar 117.52 dan jika dibandingkan dengan $\chi^{2}$ tabel nilai ini jauh lebih besar. Dari nilai probabilitas LR Statistik ini tentunya akan menunjukkan hal yang sama dengan nilai probabilitas yang lebih kecil dari level signifikansi 5\%. Karena itu lah cukup bukti untuk menolak hipotesis nol, atau variabel penjelas secara bersama-sama mampu menjelaskan variabel terikat. PAD, proporsi penduduk miskin, luas wilayah, belanja perjalanan dinas dan BHSDA secara bersama-sama signifikan dalam menjelaskan probabilitas daerah menerima DAU di atas rata-rata. Ringkasnya, model signifikan dalam menjelaskan variabel terikat. Dari tingkat kesesuaian suai (goodness of fit), model ini layaknya model heteroskedastisitas memiliki nilai yang tidak terlalu tinggi. Dalam model OLS sederhana, ukuran yang biasa digunakan adalah nilai $\mathrm{R}^{2}$. Namun, dalam probit hal ini sedikit berbeda ukuran yang digunakan adalah McFadden $\mathrm{R}^{2}$. diukur dengan formula 1 - (rasio antara restrictred log likelihood dengan average log likelihood). Hasil estimasi yang kita lakukan terlihat bahwa nilai McFadden $\mathrm{R}^{2}$ sama dengan 0,26. Hal ini menunjukkan bahwa $26 \%$ variasi dari variabel terikat dapat dijelaskan oleh variasi pada variabel-variabel penjelas. Dengan kata lain $26 \%$ variasi dari probabilitas daerah menerima DAU di atas rata-rata dapat dijelaskan oleh variasi pada model.

Bagian yang paling berbeda dengan estimasi pada model OLS sederhana adalah cara mengartikan koefisiennya. Koefisien dalam model probit tidak dapat dengan serta merta diartikan 
sebagai dampak marginal dari perubahan variabel bebas kepada variabel terikat. Koefisien dalam model probit dapat diartikan dampak pada nilai z dari perubahan satu variabel bebas dengan mengasumsikan variabel lainnya tetap. Pengartian dari koefisien ini akan dapat kita lihat pada bagian pembahasan berikut ini

\section{VI.2 Pembahasan}

Untuk menginterpretasikan koefisien dalam model probit, maka kita harus menghitung nilai z dan kemudian dihitung nilai probabilitasnya. Sebagai contoh, kita ingin melihat koefisien dari komponen PAD terhadap penentuan besarnya probabilitas daerah menerima DAU di atas rata-rata, maka kita tentukan nilai z terlebih dahulu, seperti ditunjukkan di bawah ini:

$Z=(-2.78+3.12 * P O O R+0.77 * P A D-0.11 * B H S D A-0.17 * B E L D I N+0.21 * W I L)$ dan kita ganti POOR dengan nilai rata-ratanya (karena variabel kontinu, yaitu 0,24 ) dan anggap variabel BHSDA, BELDIN dan WIL konstan pada nilai 2. Maka nilai Z ketika PAD sama dengan satu sama dengan $-1,4177$ dan ketika PAD sama dengan 2, nilai $Z$ sama dengan -0,64308. Nilai probabilitas untuk $Z=-1,4177$ sama dengan $7,8 \%$ sedangkan untuk $Z=-0,64308$ nilai probabilitasnya sama dengan $26 \%$.

Dari hasil perhitungan di atas terlihat bahwa probabilitas daerah untuk menerima DAU di atas rata-rata akan berbeda sebesar 18,2\% antar daerah yang memiliki nilai PAD pada kuartil pertama dan kedua. Probabilitas ini semakin meningkat seiring dengan meningkatnya PAD (dengan asumsi variabel penjelas lain tetap) dan ketika nilai PAD pada kuartil keempat, probabilitas daerah menerima DAU di atas rata-rata menjadi $82 \%$. Probabilitas ini akan semakin bertambah besar jika suatu daerah memiliki luas wilayah yang cukup besar dan berada pada kuartil keempat. Probabilitas tersebut menjadi 91\% menerima DAU di atas rata-rata. Secara implisit hal ini juga menunjukkan bahwa tanda pada koefisien sejalan dengan pengaruh dari variabel penjelas terhadap probabilitas daerah menerima DAU di atas rata-rata.

Analisis yang sama dapat kita pergunakan untuk menganalisis koefisien pada luas wilayah. Ketika luas wilayah suatu daerah berada pada kuartil pertama maka akan kita peroleh nilai Z sama dengan -0,849 dengan nilai probabilitas sama dengan 19,8\%. Ketika suatu daerah memiliki daerah yang lebih luas dan berada pada kuartil kedua maka diperoleh nilai Z sama dengan 0,643 dengan nilai probabilitas sama dengan 26\%. Peningkatan kuartil luas wilayah dari 1 ke 2 merubah probabilitas menerima DAU di atas rata-rata menjadi 6,2\%. Perubahan ini lebih kecil dari perubahan probabilitas pada PAD yang jika berubah dari kuartil 1 ke 2 probabilitas berubah menjadi 18,2\%. Kondisi ini sejalan dengan besarnya koefisien PAD yang lebih besar dari koefisien luas wilayah. 
Pengaruh positif PAD terhadap probabilitas daerah menerima DAU di atas rata-rata ini tidak sejalan dengan formula DAU yang telah ditetapkan oleh pemerintah. Hal ini justru membuktikan hipotesis yang telah dibangun oleh penulis bahwa terjadi tekanan politik dari daerah yang kaya (yang ditunjukkan dengan besarnya PAD) untuk menerima DAU yang besar pula. Jika kita kembali kepada konsep pemerataan dalam alokasi DAU, sudah seharusnya lah daerah yang memiliki PAD yang tinggi, yang notabene memiliki kapasitas fiskal yang besar, menerima DAU yang relatif rendah dan bukan sebaliknya. Kondisi ini menunjukkan bahwa tekanan politik daerah kaya sangat besar dalam alokasi DAU, ditunjang dengan digunakannya estimasi PAD dalam formula DAU yang terkadang lebih rendah dibandingkan PAD aktualnya khususnya bagi daerah kaya yang memiliki PAD sangat besar.

Proporsi penduduk miskin pada suatu daerah serta luas wilayah memiliki hubungan yang positif dengan probabilitas daerah menerima DAU di atas rata-rata. Hal ini sejalan dengan formula DAU, karena komponen ini merupakan komponen kebutuhan fiskal daerah yang mempunyai hubungan positif dengan penerimaan alokasi DAU. Satu hal yang menarik adalah komponen Bagi Hasil Sumber Daya Alam (BHSDA). Variabel BHSDA dari hasil estimasi memang memiliki hubungan yang negatif, namun estimasi juga menunjukkan bahwa variabel ini tidak mempengaruhi secara signifikan. Sehingga dapat disimpulkan bahwa besarnya BHSDA di suatu daerah tidak menjadi faktor yang mempengaruhi probabilitas daerah menerima DAU di atas rata-rata. Fakta ini sekali mendukung hipotesis yang penulis bangun, bahwa terjadi tekanan politis dari daerah kaya untuk menerima DAU yang lebih besar.

Model ini tidak berhasil membuktikan bahwa terjadi lobi antara aparat pemerintah daerah kepada pemerintah pusat untuk menerima DAU di atas rata-rata. Variabel lobi yang kita wakili dengan Belanja Perjalanan Dinas memiliki hubungan yang negatif dan signifikan dalam menjelaskan probabilitas daerah menerima DAU di atas rata-rata. Penulis sangat menyadari bahwa penggunaan Belanja Perjalanan Dinas sebagai proksi dari lobi, sangat lah lemah. Sangat sulit membagi komponen pengeluaran ini berdasarkan tujuan perjalanan yang dilakukan oleh aparat pemerintah daerah. Selain itu, jika pun ada lobi dan upaya suap dari aparat pemerintah daerah, sumber dana yang digunakan dimungkinkan tersebar pada banyak mata anggaran dalam APBD. Penulis mengangap ini adalah kelemahan utama dari studi ini. Pada studi berikutnya, penulis merasakan untuk perlu menyempurnakan penggunaan variabel penjelas dalam model yang kita gunakan.

Sebagai kesimpulan penulis, dalam alokasi DAU digunakan formula-formula tertentu. Karenanya penggunaan variabel dalam formula relatif diperkirakan tidak akan berubah jauh yang seperti terdapat dalam formula. Namun, studi ini menemukan fakta lain khususnya yang berkaitan dengan kapasitas fiskal. Dari sisi kebutuhan fiskal, arah pengaruh dapat tepat sama 
dengan formula yang ada, yaitu berpengaruh positif. Studi yang akan datang akan lebih memperlihatkan dengan jelas jika dibahas pada dana perimbangan dari pemerintah pusat kepada pemerintah daerah yang belum jelas alokasi dananya, misalnya Dana Alokasi Khusus.

\section{KESIMPULAN DAN REKOMENDASI}

\section{VII.1 Kesimpulan}

Hasil studi yang dilakukan penulis menunjukkan bahwa terjadinya tekanan politik daerah kaya yang dibuktikan dengan besarnya PAD yang berhubungan positif dengan probabilitas daerah menerima DAU di atas rata-rata serta tidak signifikannya BHSDA dalam mempengaruhi probabilitas daerah menerima DAU. Selain itu, variabel kebutuhan fiskal berhubungan positif dengan probabilitas menerima DAU di atas rata-rata. Kondisi ini sejalan dengan formula DAU yang ada.

Probabilitas daerah menerima DAU semakin bertambah besar dengan meningkatnya pendapatan asli daerah yang ditunjukkan dengan probabilitas tersebut meningkat 18,2\% dari daerah yang memiliki PAD pada kuartil pertama dan kedua. Probibilitas tersebut meningkat menjadi $91 \%$ jika suatu daerah memiliki PAD dan luas wilayah pada kuartil 4.

Fakta ini hendaknya menjadi perhatian pemerintah pusat jika ingin mengurangi kesenjangan pembangunan antara daerah. Sudah selayaknya lah daerah yang kaya memiliki alokasi DAU yang sedikit, sedangkan daerah yang miskin akan memiliki alokasi DAU yang relatif besar. Peran pemerintah pusat harus menciptakan mekanisme alokasi DAU yang lebih tegas dan transparan, begitu pula dengan cara pengambilan data yang digunakan sebagai data dasar dalam alokasi DAU. Semakin transparan pemerintah pusat, maka akan semakin mengikis ketidakpercayaan pemerintah daerah kepada pemerintah pusat dan akan mengurangi ketidakpuasan daerah kepada pemerintah pusat.

\section{VII.2 Rekomendasi}

Berdasarkan studi yang telah dilakukan penulis, maka penulis memberikan rekomendasi kepada pemerintah khususnya pemerintah pusat untuk memperbaiki kinerja alokasi DAU pada masa yang akan datang. Disinyalir telah terjadi tekanan politik dari daerah kaya kepada pemerintah pusat untuk menerima DAU di atas rata-rata.

Perbaikan itu bisa menyangkut tentang transparansi formula serta transparansi data yang dapat diakses oleh seluruh pemerintahan daerah di Indonesia. Selain itu, perbaikan kualitas data di tingkat daerah, akan semakin meningkatkan ketepatan alokasi DAU. 


\section{VII.3 Keterbatasan Studi}

Kelemahan utama dari studi ini adalah data Belanja Perjalanan Dinas sebagai proksi dari variabel lobi antara pemerintah daerah dengan pemerintah pusat. Seperti diketahui bahwa dalam data APBD, komponen ini diagregasikan secara utuh. Akan sangat sulit kita membedakan mana biaya perjalanan dinas yang digunakan untuk pergi ke Jakarta atau pergi ke Jakarta dalam rangka melobi aparat pemerintah pusat. Selain itu, komponen biaya lobi ini dimungkinkan tersebar pada mata item anggaran lainnya dalam APBD. Karena itulah penggunaan variabel ini sebagai indikator lobi sangat lah lemah. Namun, tindakan penulis untuk mewakili variabel tersebut didasarkan pada keterbatasan data yang mendekati komponen lobi dari pemerintah daerah. Selain itu, keputusan untuk memasukkan variabel ini tidak terlepas dari isu yang berkembang tentang maraknya aparat pemerintah daerah pergi ke Jakarta untuk melobi pemerintah pusat sehingga untuk pergi tersebut dimungkinkan tercermin dalam mata anggaran APBD belanja perjalanan dinas. 


\section{DAFTAR PUSTAKA}

UU No. 22 Tahun 1999 tentang Pemerintahan Daerah

UU No. 25 Tahun 1999 tentang Perimbangan Keuangan antara Pemerintah Pusat dan Daerah Usui, Nario and Armida Alisjahbana. Local Development Planning and Budgeting in Decentralized Indonesia: Key Issues. A Paper Presented in Indonesian-Japanese on Indonesia's Decentralization, 2003

Syahrial, Syarif. Fiscal Decentralization and Government Size: The Case Study of Indonesia (forthcoming)

Nota Keuangan Republik Indonesia, Departemen Keuangan RI, berbagai tahun penerbitan.

Syahrial, Syarif. Otonomi Khusus: Tinjauan Singkat dari Sisi Perekonomian dan Keuangan Daerah. Wacana Alumni Diklat LPEM FEUI.

Brodjonegoro and Mahi. The Indonesian Political Economy of Decentralization. A Paper Presented in Indonesian-Japanese on Indonesia's Decentralization, 2003

Sidik, Machfud et.all. Dana Alokasi Umum. Dirjen PKPD, MPKP FEUI dan LPEM FEUI (Jakarta: 2002) Mello de, Luiz. Fiscal Decentralization and Government Size: Case of Moldova. (IMF Working Paper: 2003)

Ghozali, Abbas. Modul Ekonometrika II Pascasarjana IImu Ekonomi FEUI. Catatan Kuliah (Jakarta:2004)

Verbeek, Marno. A Guide to Modern Econometrics. (Chichester: John Wiley \& Sons, 2000)

Chevalier, Arnaud. Limited Dependent Variable. (University College Dublin: 2004)

Judge, George G et.all. Introduction to the Theory and Practice of Econometrics. (New York: John Wiley and Sons, 1982) 